Advances in Geosciences, 6, 69-72, 2006

SRef-ID: $1680-7359 /$ adgeo/2006-6-69

European Geosciences Union

(c) 2006 Author(s). This work is licensed

under a Creative Commons License.

\title{
A synthesis of ENSO effects on drylands in Australia, North America and South America
}

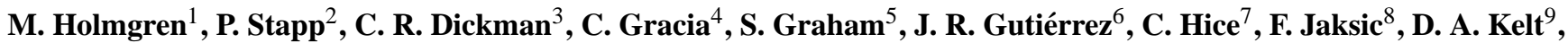 \\ M. Letnic ${ }^{10}$, M. Lima ${ }^{8}$, B. C. López ${ }^{4}$, P. L. Meserve ${ }^{11}$, W. B. Milstead ${ }^{12}$, G. A. Polis ${ }^{13, \dagger}$, M. A. Previtali ${ }^{11}$, M. Richter ${ }^{14}$, \\ S. Sabaté ${ }^{4}$, and F. A. Squeo ${ }^{6}$ \\ ${ }^{1}$ Resource Ecology Group, Wageningen University, Bornsesteeg 69, Building 119, 6708 PD Wageningen, The Netherlands \\ ${ }^{2}$ Department of Biological Science, California State University, PO Box 6850, Fullerton, CA 92834-6850, USA \\ ${ }^{3}$ Institute of Wildlife Research, University of Sydney, NSW 2006, Australia \\ ${ }^{4}$ Dept. d'Ecologia, Fac. de Biologia, Univ. de Barcelona; Av Diagonal, 645; 08028 Barcelona, Catalunya, Spain \\ ${ }^{5}$ CSIRO Sustainable Ecosystems, GPO Box 284, Canberra ACT 2601, Australia \\ ${ }^{6}$ Departamento de Biología, Universidad de La Serena, Casilla 599 and Centro de Estudios Avanzados en Zonas Áridas \\ (CEAZA), La Serena, Chile \\ ${ }^{7}$ Department of Biology, University of New Mexico, Albuquerque, NM 87131, USA \\ ${ }^{8}$ Center for Advanced Studies in Ecology and Biodiversity (CASEB), Santiago, Chile \\ ${ }^{9}$ Dept. of Wildlife, Fish and Conservation Biology, University of California, Davis, CA 95616, USA \\ ${ }^{10}$ Parks and Wildlife Service of Northern Territory, P.O. Box 30, Palmerston NT, 0831 Australia \\ ${ }^{11}$ Northern Illinois University, DeKalb, IL 60115, USA \\ ${ }^{12}$ National Park Service, University of Rhode Island, Kingston, RI 02881, USA \\ ${ }^{13}$ Department of Environmental Science and Policy, University of California, Davis, CA 95616, USA \\ ${ }^{14}$ Institute of Geography, FAU, Kochstr. 4/4, D 91054 Erlangen, Germany
}

Received: 26 July 2005 - Revised: 26 September 2005 - Accepted: 18 October 2005 - Published: 9 January 2006

\begin{abstract}
Fundamentally, El Niño Southern Oscillation (ENSO) is a climatic and oceanographic phenomenon, but it has profound effects on terrestrial ecosystems. Although the ecological effects of ENSO are becoming increasingly known from a wide range of terrestrial ecosystems (Holmgren et al., 2001), their impacts have been more intensively studied in arid and semiarid systems. In this brief communication, we summarize the main conclusions of a recent symposium on the effects of ENSO in these ecosystems, which was convened as part of the First Alexander von Humboldt International Conference on the El Niño Phenomenon and its Global Impact, in Guayaquil, Ecuador, from 16-20 May 2005. Participants in the symposium shared results and perspectives from research conducted in North and South America and Australia, regions where the ecological effects of ENSO have been studied in depth. Although the reports covered a wide array of organisms and ecological systems (Fig. 1), a recurring theme was the strong increase in rainfall associated with ENSO events in dry ecosystems (during the El Niño phase of the oscillation in the Americas and the La Niña phase in Australia). Because inter-annual variability
\end{abstract}

in precipitation is such a strong determinant of productivity in arid and semiarid ecosystems, increased ENSO rainfall is crucial for plant recruitment, productivity and diversity in these ecosystems. Several long-term studies show that this pulse in primary productivity causes a subsequent increase in herbivores, followed by an increase in carnivores, with consequences for changes in ecosystem structure and functioning that can be quite complex.

Much of the work presented at the symposium represents research that was or will be published elsewhere. However, we take this opportunity to summarize some of the main points that emerged from our presentations and the resulting discussion on the general effects of ENSO on arid and semiarid ecosystems. 


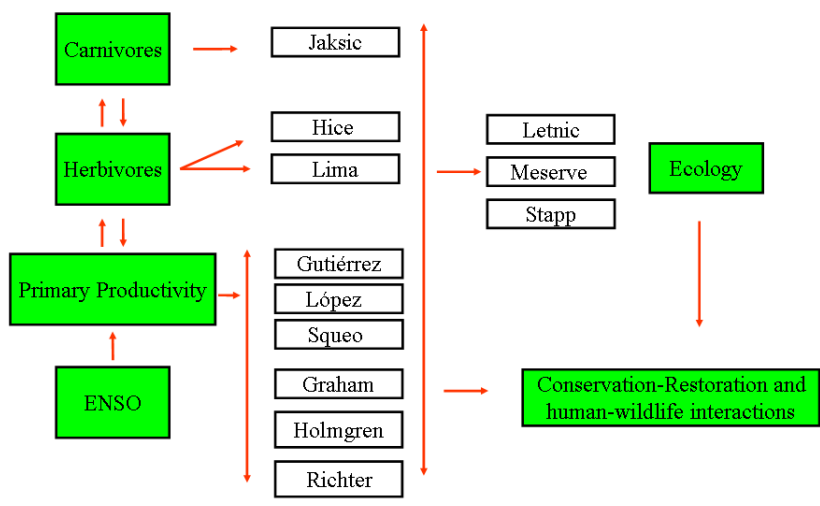

Fig. 1. Research lines on ENSO effects in dry ecosystems presented at this conference.

1. Because of its episodic and unpredictable timing and potentially overwhelming impact, ENSO events may be considered a disturbance in many arid and semiarid systems. The nature of the disturbance can be direct (flooding, erosion, drought) or indirect (changes in disease hosts, predator-prey interactions) and from a human perspective, positive or negative.

2. Species clearly differ in their response to ENSO events, often in surprising ways that may be mediated by interactions with other species. Further, there may be important regional differences in relative importance of ENSO events, within an area, as well as in the magnitude of effects of a given ENSO that may or may not be predictable based on climate data.

3. The extraordinary boost in primary productivity associated with ENSO rainfall involves rapid increases in plant cover and seed production of herbaceous species (Hamman, 1985; Dillon and Rundel, 1990; Polis et al., 1997; Vidiella et al., 1999; Block and Richter, 2000; Gutiérrez et al., 2000), as well as enhanced growth and recruitment of trees and shrubs (Austin and Williams, 1988; Nicholls, 1992; López et al., 2005).

4. Herbivores respond to ENSO-induced changes in food (plant) availability by increasing numerically during pulses of abundant primary productivity and by emigrating or having population crashes during ENSO associated droughts. Many different types of herbivores and granivores respond to these fluctuations, including arthropods (Polis et al., 1997, 1998), birds (Grant et al., 2000), and small mammals, whose response has been particularly well studied in Australia (Dickman et al., 1999, 2001; Letnic et al., 2005), in South America (Meserve et al., 2003; Jaksic and Lima, 2003) and in North America (Brown and Ernest, 2002; Stapp and Polis, 2003). Small mammal species differences in their response to ENSO events seem to depend on their feeding habits, reproductive rates and interactions with competitors and predators.
5. Vertebrate predators (including carnivorous mammals and birds of prey) display a variety of responses at all levels of organization. At the individual level, predators shift their consumption of prey over time depending on the abundance of alternative prey (Jaksic et al., 1992; Silva et al., 1995; Meserve et al., 1999). At the population level, predators increase numerically tracking the prey temporal course of abundance (Jaksic et al., 1992; Silva et al., 1995; Lima et al., 2002a; Letnic et al., 2005). Finally, at the community level, the predator assemblage as a whole shows important rearrangements of its richness, composition and structure (Jaksic et al., 1993). The most prevalent guild response is for predators to have lower diet similarity during rainy ENSO events because there is greater abundance and a broader variety of available prey.

6. In arid and semiarid systems, effects on consumers and food webs are mediated by increases in primary productivity, which result from temporary elimination of water shortage (Jaksic, 2001). Although most studies reveal that ENSO events have important bottomup effects (i.e., plants-herbivores-predators), they are also known to interact with top-down processes (i.e., predators-herbivores-plants) in influencing abundance and dynamics of lower trophic levels (Gutiérrez et al., 1997; Polis et al., 1998; Lima et al., 2002b; Letnic et al., 2005).

7. On arid islands, there is a tight interdependence of ocean and terrestrial systems mainly through the role of seabirds as providers of carrion (dead animals) for consumers and guano as a source of nutrients for plants (Sánchez-Piñero and Polis, 2000). A major consequence of ENSO is to change the relative contributions of terrestrial vs. marine sources to insular food webs (Stapp et al., 1999). The response of these insular systems to ENSO rainy pulses depend very strongly on the presence of seabirds which underscores the importance of a healthy marine environment and the protection of seabirds to the conservation of insular ecosystems.

8. The effects of ENSO events persist for months or even years beyond the actual period of abnormal ENSO conditions, in seed or litter banks or in the tissues of longlived consumers. Such pulse-reserve dynamics are characteristic of many arid and semiarid systems, and ENSO climatic events are a major driving force of these dynamics in many systems.

9. The consequences of ENSO are best illuminated by long-term, comparative studies that measure multiple resource and trophic levels (producers and consumers). Additional experimental manipulations of ENSO-related changes in resources or abiotic conditions, however, are also needed to elucidate the mechanisms involved (e.g. rainfall augmentation or food addition). 
10. ENSO-related changes in terrestrial productivity have substantial effects on human communities and land use, with important implications for restoration, natural resources management and conservation. For example, enhanced establishment of trees during rainy ENSO years could be used to restore degraded arid and semiarid ecosystems (e.g., Holmgren and Scheffer, 2001; Quispe, 2002; Vilela, 2002); conversely, dry years can reduce the success of reforestation programs (Howden et al., 2004) and increase damage to plant communities and soil via overgrazing by livestock (Ludwig et al., 1997). At the same time, the large plant biomass produced during the wet phase of ENSO provides ample fuel for fires in the subsequent dry years (Skidmore, 1987; Kitzberger et al., 2001; Letnic et al., 2004, 2005; Richter and Ise, 2005). Moreover, ENSO-related changes have strong implications for wildlife conservation and management. For instance, food abundance during rainy years can potentially increase population growth and recovery of some species; however, it can also trigger rodent irruptions that can have severe consequences for agriculture and the spread of zoonotic diseases, such as hantavirus (Hjelle and Glass, 2000; Yates et al., 2002) and plague (Stapp et al., 2004). Additionally, the subsequent increase of exotic predators may endanger native mammal or bird species (Dickman, 1996). Clearly, seasonal ENSO forecasting could be applied to adaptive management and conservation of arid and semiarid ecosystems.

11. The consequences of interactions between global climate change and ENSO are still largely unknown for terrestrial ecosystems, but given the important role of ENSO as a driver of terrestrial productivity, any effects are likely to be profound.

Acknowledgements. We all gratefully acknowledge the efforts of all the technicians, students and volunteers that have worked in these projects for many years and contributed to the success of these enterprises. We also thank the support of the organizers of this conference for facilitating the communication of our results. C. Dickman, M. Letnic and colleagues thank the Australian Research Council for continued support of their work in central Australia over the past 15 years. S. Graham thanks the Land and Water Australia's Managing Climate Variability Program for their ongoing support. J. R. Gutiérrez and F. A. Squeo thank the support by the BBVA (Spain) Foundation Prize in Research and Conservation Biology. C. Hice thanks the Centers for Disease Control and Prevention in Atlanta GA for financial support during the last ten years. M. Holmgren and colleagues thank the support by the EU-INCO project (ICA4-CT2001-10051) (www.biouls.cl/enso/). P. L. Meserve, J. R. Gutiérrez, and colleagues thank the U.S. National Science Foundation and its Chilean counterpart agency, FONDECYT for support of the work over the past 16 years. Current support is from NSF-DEB 0319966 and FONDECYT 1030225. P. Stapp thanks the U.S. National Science Foundation and Earthwatch for their support of his and Gary Polis' research in Baja California (DEB-9207855, DEB-9527888, DEB-9806657), and the Mexican government and collaborators for their assistance.
Edited by: P. Fabian and J. L. Santos

Reviewed by: J. Bendix and another referee

\section{References}

Austin, M. P. and Williams, O.: Influence of climate and community composition on the population demography of pasture species in semi-arid Australia, Vegetatio, 77, 43-49, 1988.

Block, M. A. and Richter, M.: Impacts of heavy rainfalls in El Niño 1997/98 on the vegetation of Sechura Desert in Northern Peru, Phytocoenologia, 30, 491-517, 2000.

Brown, J. H. and Ernest S. K. M.: Rain and rodents: complex dynamics in desert communities, Bioscience, 52, 979-987, 2002.

Dickman, C. R.: The impact of exotic generalist predators on the native fauna of Australia, Wildlife Biol., 2, 185-195, 1996.

Dickman, C. R., Mahon, P. S., Masters, P., and Gibson, D. F.: Longterm dynamics of rodent populations in arid Australia: the influence of rainfall, Wildlife Res., 26, 389-403, 1999.

Dickman, C. R., Haythornthwaite, A. S., McNaught, G. H., Mahon, P. S., Tamayo, B., and Letnic, M.: Population dynamics of three species of dasyurid marsupials in arid central Australia: a 10year study, Wildlife Res., 28, 493-506, 2001.

Dillon, M. O. and Rundel, P. W.: The botanical response of the Atacama and Peruvian desert floras to the 1982-83 El Niño event, in: Global Ecological Consequences of the 1982-83 El Niño Southern Oscillation, edited by: Glynn, P. W., Elsevier Oceanographic Series 52, p. 487-504, Amsterdam, 1990.

Grant, P. R., Grant, B. R., Keller, L. F., and Petren, K.: Effects of El Niño events on Darwin's finch productivity, Ecology, 81, 2442-2457, 2000.

Gutiérrez, J. R., Meserve, P. L., Herrera, S., Contreras, L. C., and Jaksic, F. M.: Effects of small mammals and vertebrate predators on vegetation in the Chilean semiarid zone, Oecologia, 109, 398 406, 1997.

Gutiérrez, J. R., Arancio, G., and Jaksic, F. M.: Variation in vegetation and seed bank in a Chilean semi-arid community affected by ENSO 1997, J. Veg. Sci., 11, 641-648, 2000.

Hamman, O.: The El Niño influence on the Galápagos vegetation, in: El Niño en las Islas Galápagos: el evento de 1982-1983, edited by: Robinson, G. and Del Pino, E. M., Fundación Charles Darwin para las Islas Galápagos, Quito, p. 299-330, 1985.

Hjelle, B. and Glass, G. E.: Outbreak of hantavirus infection in the Four Corners region of the United States in the wake of the 1997 1998 El Niño-Southern Oscillation, J. Infect. Dis., 181, 1569_ 1573, 2000.

Holmgren, M. and Scheffer, M.: El Niño as a window of opportunity for the restoration of degraded arid ecosystems, Ecosystems, 4, 151-159, 2001

Holmgren, M., Scheffer, M., Ezcurra, E., Gutiérrez, J. R., and Mohren, G. M. J.: El Niño effects on the dynamics of terrestrial ecosystems, Trends Ecol. Evol., 16, 89-94, 2001.

Howden, S. M., Crimp, S., Carter, J., O'Connell, D., Carr, D., McIvor, J., and Graham, S.: Enhancing natural resource management by incorporating climate variability into tree establishment decisions - final report for Land and Water Australia, CSIRO, Canberra, 2004.

Jaksic, F. M.: Ecological effects of El Niño in terrestrial ecosystems of western South America, Ecography, 24, 241-250, 2001.

Jaksic, F. M. and Lima, M.: Myths and facts on ratadas: bamboo blooms, rainfall peaks and rodent outbreaks in South America, Austral Ecol., 28, 237-251, 2003. 
Jaksic, F. M., Jiménez, J. E., Castro, S. A., and Feinsinger, P.: Numerical and functional response of predators to a long-term decline in mammalian prey at a semi-arid Neotropical site, Oecologia, 89, 90-101, 1992.

Jaksic, F. M., Feinsinger, P., and Jiménez, J. E.: A long-term study on the dynamics of guild structure among predatory vertebrates at a semi-arid neotropical site, Oikos, 67, 87-96, 1993.

Kitzberger, T., Swetnam, T. W., and Veblen, T. T.: Interhemispheric synchrony of forest fires and the El Niño-Southern Oscillation, Global Ecol. Biogeogr., 10, 315-326, 2001.

Letnic, M., Dickman, C. R., Tischler, M., Tamayo, B., and Beh, C.-L.: The responses of small mammals and lizards to fire and rainfall in arid Australia, J. Arid Environ., 59, 85-114, 2004.

Letnic, M., Tamayo, B., and Dickman, C. R.: The responses of mammals to La Niña (El Niño Southern Oscillation) - associated rainfall, predation, and wildfire in central Australia, J. Mammal., 86, 689-703, 2005.

Lima, M., Stenseth, N. C., and Jaksic, F. M.: Food web structure and climate effects on the dynamics of small mammals and owls in semiarid Chile, Ecol. Lett., 5, 273-284, 2002a.

Lima, M., Stenseth, N. C., and Jaksic, F. M.: Population dynamics of a South American small rodent: seasonal structure interacting with climate, density-dependence and predator effects, Proc. Roy. Soc. Lond. B, 269, 2579-2586, 2002b.

López, B. C., Sabaté, S., Gracia, C. A., and Rodríguez R.: Wood anatomy of Prosopis pallida from Peru and its suitability for dendrochronology, J. Arid Environ., 61, 541-554, 2005.

Ludwig, J., Tongway, D., Freudenberger, D., Noble, J., and Hodgkinson, K.: Landscape ecology function and management: Principles from Australia's rangelands, CSIRO, Canberra, Australia, 1997.

Meserve, P. L., Milstead, W. B., Gutiérrez, J. R., and Jaksic, F. M.: The interplay of biotic and abiotic factors in a semiarid Chilean mammal assemblage: results of a long-term experiment, Oikos, 85, 364-372, 1999.

Meserve, P. L., Kelt, D. A., Milstead, W. B., and Gutiérrez, J. R.: Thirteen years of shifting top-down and bottom-up control, BioScience, 53, 633-646, 2003.

Nicholls, N.: Historical El Niño/Southern Oscillation variability in the Australasian region. In Diaz H. F., and Markgraf, V.: El Niño: historical and paleoclimatic aspects of the Southern Oscillation, Cambridge University Press, New York, 1992.

Polis, G. A., Hurd, S. D., Jackson, C. T., and Sánchez Piñero, F.: El Niño effects on the dynamics and control of an island ecosystem in the Gulf of California, Ecology, 78, 1884-1897, 1997.
Polis, G. A., Hurd, S. D., Jackson, C. T., and Sánchez Piñero, F. Multifactor population limitation: variable spatial and temporal control of spiders on Gulf of California islands, Ecology, 79, 490-502, 1998.

Quispe, F.: Repoblamiento en bosques secos de colina en el Departamento de Tumbes durante el Fenómeno El Niño 1997, Serie Lecciones Aprendidas No. 7, INRENA - Proyecto Algarrobo, Perú, 2002.

Richter, M. A. and Ise, M.: Monitoring plant development after El Niño 1997/98 in Northwestern Peru, Erdkunde, 59, 136-155, 2005.

Sánchez-Piñero, F. and Polis, G. A.: Bottom-up dynamics of allochthonous input: direct and indirect effects of seabirds on islands, Ecology, 81, 3117-3132, 2000.

Silva, S. I., Lazo, I., Silva-Aránguiz, E., Jaksic, F. M., Meserve, P L., and Gutiérrez, J. R.: Numerical and functional response of Burrowing Owls to long-term mammal fluctuations in Chile, J. Raptor Res., 29, 250-255, 1995.

Skidmore, A. K.: Predicting bushfire activity in Australia from El Niño Southern Oscillation Events, Aust. Forestry, 50, 231-235, 1987.

Stapp, P., Polis, G. A., and Sánchez Piñero, F.: Stable isotopes reveal strong marine and El Niño effects on island food webs, Nature 401, 467-469, 1999.

Stapp, P., and Polis, G. A.: Influence of pulsed resources and marine subsidies on insular rodent populations, Oikos, 102, 111-123, 2003.

Stapp, P., Antolin, M. F., and Ball, M.: Patterns of extinction in prairie-dog metapopulations: plague outbreaks follow El Niño events, Front. Ecol. Environ., 2, 235-240, 2004.

Vidiella, P. E., Armesto, J. J., and Gutiérrez, J. R.: Vegetation change and sequential flowering after rain in the southern Atacama Desert, J. Arid Environ., 43, 449-458, 1999.

Vilela, P.: Reforestación participativa en Piura durante el Fenómeno El Niño 1996-1997. Serie Lecciones Aprendidas No. 8, INRENA - Proyecto Algarrobo, Perú, 2002.

Yates, T. L., Mills, J. N., Parmenter, C. A., Ksiazek, T. G., Parmenter, R. R., Vande Castle, J. R., Calisher, C. H., Nichol, S. T. Abbot, K. D., Young, J. C., Morrison, M. L., Beaty, B. J., Dunnum, J. L., Baker, R. J., Salazar-Bravo, J., and Peters, C. J.: The ecology and evolutionary history of an emergent disease: hantavirus pulmonary syndrome, Bioscience, 52, 989-998, 2002. 